\title{
Presymptomatic diagnosis for children of sporadic neurofibromatosis 2 patients: A method based on tumor analysis
}

\author{
Lan Kluwe, $P h D^{1}$, Reinhard E. Friedrich, $M D^{2}$, Marcos Tatagiba, $M D^{3}$, and Victor F. Mautner, $M D^{4}$
}

\begin{abstract}
Purpose: To provide presymptomatic diagnosis for children of sporadic neurofibromatosis 2 patients in whom no NF2-mutations were found by screening their blood-DNA. Methods: Tumors of four patients were analyzed for NF2 allele losses and mutations. Results: Nonsense NF2 mutations and NF2 allele losses were found in all tumors. None of these alterations was found in any of eight children examined, suggesting that these children did not inherit the disease. Conclusions: Finding two genetic alterations of a tumor suppressor gene in associated tumors is useful for presymptomatic diagnosis. Identification of the lost allele in tumors alone also enables exclusion of disease transmission in 50\% of cases. Genet Med 2002:4(1):27-30.
\end{abstract}

Key Words: NF1, loss of heterozygosity, mosaicism, presymptomatic diagnosis

Neurofibromatosis 2 (NF2) is a genetic disorder with an incidence of 1:40,000. Although bilateral vestibular schwannomas are the hallmark of this autosomal dominant disorder, ${ }^{1-3}$ other cerebral tumors (e.g., meningiomas), cutaneous tumors, ${ }^{4}$ and ophthalmologic abnormalities ${ }^{5}$ are also common. NF2 is caused by mutations in the NF2 tumor suppressor gene on the long arm of chromosome 22.6,7 More than half of NF2 patients are sporadic and, thus, have new mutations. ${ }^{8}$ Recent findings suggest that $20 \%$ to $30 \%$ of sporadic NF2 patients may be mosaic. ${ }^{9,10}$ In some mosaic cases, the leukocytes of the patients may not bear the mutations and, thus, the mutations cannot be found by screening their blood-DNA. Our previous study demonstrated that, in such cases, analysis of tumors can provide an additional opportunity to find constitutional mutations. ${ }^{10}$ In the present study, we used tumor analysis for presymptomatic diagnosis for eight children of four sporadic NF2 patients in whom no NF2 mutations were found by screening their blood-DNA.

\section{PATIENTS AND METHODS}

Neurofibromatosis 2 patients were ascertained through our outpatient NF clinic at Hamburg, in cooperation with the Department of Neurosurgery, Hospital Nordstadt, and Hannover Medical School, Hannover, Germany. The diagnosis of NF2 was based on the updated NIH criteria. ${ }^{11}$ Single vestibular

\footnotetext{
From the ${ }^{1}$ Laboratory for Brain Tumor Biology, Department of Neurosurgery; ${ }^{2}$ Department of Oral and Maxillofacial Surgery, University Hospital Eppendorf, Hamburg; ${ }^{3}$ Department of Neurosurgery, Medical College Hannover; and ${ }^{4}$ Department of Neurology, Klinikum Nord Ochsenzoll, Hamburg, Germany.

Lan Kluwe, PhD, Laboratory for Brain Tumor Biology, Department of Neurosurgery, University Hospital Eppendorf, Martinistr. 52, 20246 Hamburg, Germany.

Received: August 16, 2001.

Accepted: November 1, 2001.
}

schwannomas were removed from Patients 72 and 148. Three cerebral meningiomas were removed from Patient 74, and one skin schwannoma was removed from Patient 358 . For all tumors, a part was frozen at the operation. The protocol was approved by the institutional review board, and all participants provided informed consent.

DNA extraction from blood and tumors, and exon-scanning using temperature gradient gel electrophoresis (TGGE) are as described in our previous study. ${ }^{10}$ Haplotype analysis of the patients, their children, and unaffected spouses as well as allelic loss analysis of the NF2 gene in tumors were performed using five microsatellite markers flanking or within the NF2 gene: CRYB2, D22S275, NF2CA3, D22S268, and D22S430.12,13

\section{RESULTS}

As listed in Table 1, the clinical features of the four sporadic NF2 patients fulfill the updated NIH diagnostic criteria for NF2. ${ }^{11}$ The phenotypes in these patients are rather mild, however, especially with respect to the age at diagnosis. In one patient (Patient 148), a unilateral vestibular schwannoma, a single cerebral tumor, and a cataract were all found on the left side. Mutation-screening using blood-DNA and exon-scanning TGGE did not reveal any alteration in the NF2 gene in any of the four patients.

Single tumors were available from Patients 72 (vestibular schwannoma), 148 (vestibular schwannoma), and 358 (skin schwannoma), whereas three meningiomas were available from Patient 74. These tumors were subjected to loss of heterozygosity (LOH) analysis, using five flanking or intragenic microsatellite markers for the NF2 gene, as well as to NF2 mutation analysis, using exon-scanning TGGE (an example in Fig. 1). In all tumors, loss of one NF2 allele was found as revealed by LOH of informative markers. Mutations in the NF2 gene were also found in these tumors. All were nonsense mutations lead- 
Table 1

Clinical and genetic features of the patients ${ }^{a}$

\begin{tabular}{|c|c|c|c|c|c|c|c|}
\hline \multirow[b]{2}{*}{ Patient } & \multirow[b]{2}{*}{ Sex } & \multirow[b]{2}{*}{ First symptom } & \multirow[b]{2}{*}{$\begin{array}{r}\text { Age (years) at first } \\
\text { symptoms/diagnosis }\end{array}$} & \multicolumn{4}{|c|}{ Number of lesions } \\
\hline & & & & $\begin{array}{c}\text { Vestibular } \\
\text { schwannoma }\end{array}$ & $\begin{array}{l}\text { Cerebral } \\
\text { tumor }\end{array}$ & $\begin{array}{l}\text { Spinal } \\
\text { tumor }\end{array}$ & Cataract \\
\hline 72 & $\mathrm{M}$ & Vestibular schwannoma & $21 / 38$ & 2 & 0 & 0 & 2 \\
\hline 74 & $\mathrm{~F}$ & Meningioma & $44 / 44$ & 2 & 3 & Multiple & 2 \\
\hline 148 & $\mathrm{~F}$ & Vestibular schwannoma & $19 / 45$ & 1 (left) & 1 (left) & Multiple & 1 (left) \\
\hline 358 & M & Epiglotic schwannoma & $29 / 38$ & 2 & 1 & 0 & 0 \\
\hline
\end{tabular}

${ }^{a}$ Patients 72 and 148 have been described previously. ${ }^{12} \mathrm{M}$, male; F, female.

ing to truncation of the NF2 gene product (Table 2). An identical mutation was found in all three different tumors from Patient 74, suggesting that it is constitutional because it is unlikely that the same somatic mutations occurred in three different tumors. For the other three patients, the mutations found are also likely to be constitutional, although we cannot exclude the possibility that the allelic loss of the NF2 gene represents constitutional microdeletion of the NF2 region. Lack of the mutations in blood-DNA of the four patients can be explained by mosaicism.

Patient 148 had one, patients 72 and 358 had two each, and Patient 74 had three children. Haplotypes of the NF2 gene region was determined for the patients, the children, and unaffected spouses of the patients. Blood-DNA of the children was also examined for the NF2 mutations that were found in tumors of their affected parents. Figure 1 shows an example of analysis of blood and tumor DNA from Patient 358 and bloodDNA from his two children. In total, five children (Children $72.1,72.2,74.3,148.1$ and 358.2) inherited the NF2 alleles that were lost in the tumors of their affected parents (designated as allele-2 in Table 2) and, thus, did not inherit the mutationbearing alleles. Indeed, the mutations found in the tumors of

A

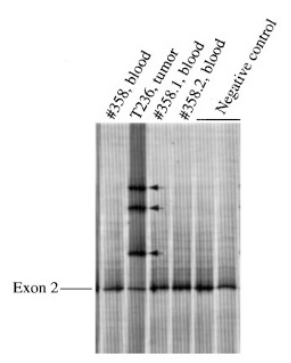

B

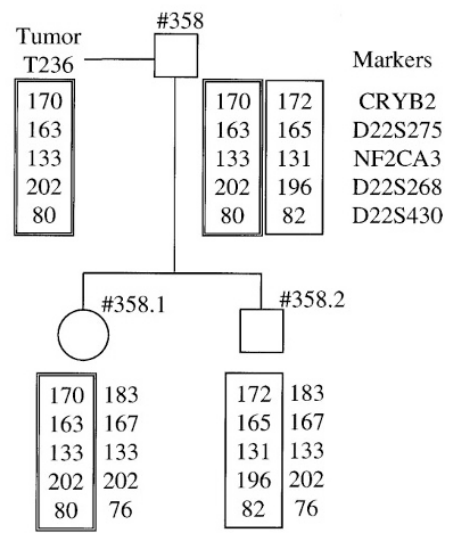

Fig. 1 Analysis of blood and tumor DNA from Patient 358 and blood-DNA from his two children. A: TGGE analysis. Additional bands (arrays) due to a mutation of 193C $\rightarrow \mathrm{T}$ in exon 2 were detected in the tumor (T236) but not in the blood-DNA of Patient 358 or in the two Children 358.1 and 358.2. B: Haplotyping analysis. The allele boxed with single lines was lost in the tumor and inherited by Child 358.2. The allele boxed with double lines remained in the tumor and bore the mutation. This allele was inherited by Child 358.1 the patients were not detected in the blood of these five children. The other three children inherited the NF2 alleles that remained and were mutated in the tumors of their affected parents (designated as allele-1 in Table 2). However, the mutations were not found in the blood of these children. This finding may be explained by the possibility that some or all germline cells of their affected parents were spared from the mutations due to mosaicism. Therefore, we were able to exclude inheritance of NF2 for all eight children of four affected parents.

\section{DISCUSSION}

By screening exons using blood-DNA, NF2 mutations have been found in between $30 \%$ and $60 \%$ of screened patients. ${ }^{14-18}$ There are several explanations for the missing mutations: mosaicism in sporadic NF2 patients, ${ }^{9,10}$ exon or multiexon deletions, insertion between exons, mutations in introns that disturb splicing, and alterations in the gene-regulatory regions. For sporadic cases, presymptomatic/prenatal diagnosis has not been possible without identified constitutional NF2 mutations. Although linkage analysis can be applied for families with at least two affected members, its practical application is limited because more than half of NF2 cases are sporadic, and, in familial cases, it is often not possible to obtain blood from more than one affected member. In the present study, we demonstrated that analysis of tumors of sporadic NF2 patients enables presymptomatic/prenatal diagnosis in the absence of identified NF2 mutations after screening blood-DNA. This is because, if we can find two genetic alterations (e.g., one mutation and one allele loss of the NF2 gene, or two mutations) in tumor(s) of a patient, we know that one of them is constitutional. We can, thus, examine children/fetuses for either genetic alteration and determine whether or not they have inherited the disease.

Three children in this study inherited the alleles that carried the mutations in the tumors of their affected parents. However, the mutations were not found in the blood of these children. This finding can be explained by the possibility that some or all germline cells of the patients do not have the mutations due to gonadal mosaicism. This result is in concordance with the expectation and previous finding ${ }^{9}$ that the risk of disease-transmission from founders to the next generation is reduced to 
Table 2

Status of mutations and allelic loss of the NF2 gene in the tumors of the patients and in their children

\begin{tabular}{|c|c|c|c|c|c|}
\hline \multirow[b]{2}{*}{ Patient } & \multicolumn{2}{|c|}{ In the tumor } & \multirow[b]{2}{*}{ Child } & \multirow{2}{*}{$\begin{array}{l}\text { Allele inherited } \\
\text { from the patient }\end{array}$} & \multirow[b]{2}{*}{ Mutation } \\
\hline & Allele-1 (mutation $\left.{ }^{a}\right)$ & Allele-2 & & & \\
\hline \multirow[t]{2}{*}{72} & Exon 2: $169 \mathrm{C} \rightarrow \mathrm{T}$ & Lost & 72.1 & Allele-2 & No \\
\hline & & & 72.2 & Allele-2 & No \\
\hline \multirow[t]{3}{*}{74} & Exon $6: 586 \mathrm{C} \rightarrow \mathrm{T}$ & Lost & 74.1 & Allele-1 & No \\
\hline & & & 74.2 & Allele-1 & No \\
\hline & & & 74.3 & Allele-2 & No \\
\hline 148 & Exon 13: $1396 \mathrm{C} \rightarrow \mathrm{T}$ & Lost & 148.1 & Allele-2 & No \\
\hline \multirow[t]{2}{*}{358} & Exon 2: $193 \mathrm{C} \rightarrow \mathrm{T}$ & Lost & 358.1 & Allele-1 & No \\
\hline & & & 358.2 & Allele-2 & No \\
\hline
\end{tabular}

${ }^{a}$ All mutations are nonsense mutations.

below 50\%, which is the expected transmission rate in a dominant genetic disorder.

Our study further demonstrated that identification of the lost NF2 alleles in the tumors of the patients alone also enables presymptomatic/prenatal diagnosis in some cases. This is because statistically $50 \%$ of children/fetuses inherit the alleles that were lost in the tumors of their affected parents (e.g., Children 72.1 and 72.2 in this study, Table 2). According to the "two-hit" model, the allele lost in the tumor is the normal allele, and the allele retained may then be inferred to be that carrying the constitutional mutation. These $50 \%$ of children/ fetuses, thus, have not inherited the mutation-bearing alleles. Although in a mosaic case, it is possible that the allele-loss represents a constitutional microdeletion of the NF2 region, disease transmission to these $50 \%$ of children/fetuses can still be excluded because they inherited the allele and thus did not inherit the microdeletion. Furthermore, it is often possible to examine whether the apparent allelic loss is constitutional, because most somatic allelic loss involves large chromosomal regions or the whole chromosome. For the other $50 \%$ of children/fetuses who inherited the alleles that remained in the tumors of their affected parents, high risk for inheriting the disease is expected. However, due to mosaicism in $20 \%$ to $30 \%$ of sporadic NF2 cases, a small portion of children or fetuses in this group may not inherit the genetic defect (e.g., Children 74.1 and 74.2 in this study, Table 2). Further studies are needed to determine the extent to which the disease transmission risk is reduced in sporadic NF2 cases. For application of this LOH analysis-based presymptomatic/prenatal diagnosis, careful clinical diagnosis of the NF2 patients is extremely important. Non-NF2 patients who present with clinical symptoms and genetic alterations similar to NF2, e.g., schwannomatosis, ${ }^{19,20}$ should be excluded. For clinically ascertained NF2 cases, the LOH analysis-based presymptomatic/prenatal diagnosis has several advantages: (1) it is unnecessary to find a mutation and can, therefore, be applied in cases in which no mutations have been found; (2) it is applicable for familial and sporadic cases, whereas linkage analysis can only be used in familial cases; (3) it includes only simple $\mathrm{LOH}$ analysis using four to six microsatellite markers and, thus, is inexpensive, fast, and requires only very small amounts of DNA. The possibility of obtaining data within 2 days is especially advantageous for prenatal diagnosis. Major limitations are the availability of tumors and that it can only by applied for cases with LOH in at least one tumor. Therefore, it is important to obtain as many tumors as possible to increase the probability of finding LOH. Skin tumors, which are present in approximately half of NF2 patients, ${ }^{4}$ may serve as a tumor source for such testing because they can be removed easily. ${ }^{21}$

Presymptomatic/prenatal diagnosis based on tumor analysis can also be applied for other tumor suppressor gene syndromes, such as retinoblastomas, ${ }^{22}$ tuberous sclerosis, ${ }^{23}$ von Hippel-Lindau disease, ${ }^{24}$ and neurofibromatosis 1 (NF1). NF1 patients often have a large number of neurofibromas, ${ }^{25}$ which can be easily removed. This condition ensures $\mathrm{LOH}$ identification in one or more of the tumors, which would enable testing to exclude NF1 transmission in $50 \%$ of children/fetuses of affected parents. Because mosaicism is frequent in NF2 and in some cases is the reason for the failure to find NF2 mutations in blood-DNA of the patients, ${ }^{9,10}$ it would be generally desirable for a genetic analysis of a sporadic NF2 patient to start with screening bloodDNA; if no mutation can be found, then screening tumor specimens whenever possible is the next step.

\section{Acknowledgments}

Supported by the von Recklinghausen Gesellschaft.

\section{References}

1. Evans DGR, Huson SM, Donnai D, Neary W, Blair V, Newton V, Harris R. A clinical study of type 2 neurofibromatosis. Q J Med 1992;84:603-618.

2. Parry DM, Eldridge R, Kaiser-Kupfer MI, Bouzas EA, Pikus A, Patronas N. Neurofibromatosis 2 (NF2) clinical characteristics of 63 affected individuals and clinical evidence for heterogeneity. Am J Med Genet 1994;52:450-461.

3. Mautner VF, Lindenau M, Baser ME, Hazim W, Tatagiba M, Haase W, Samii M, Wais R, Pulst SM. The neuroimaging and clinical spectrum of neurofibromatosis 2 . Neurosurgery 1996;38:880-885. 


\section{Kluwe et al.}

4. Mautner VF, Lindenau M, Baser M, Kluwe L, Gottschalk J. Skin abnormalities in neurofibromatosis 2. Arch Dermatol 1997;133:1539-1543.

5. Ragge NK, Baser ME, Klein J, Nechiporuk A, Sains J, Pulst S-M, Riccardi VM. Ocular abnormalities in neurofibromatosis 2. Am J Ophthalmol 1995;129:634-641.

6. Rouleau GA, Merel P, Lutchman M, Sanson M, Zucman J, Marineau C, HoangXuan K, Demczuk S, Desmaze C, Plougastel B, Pulst SM, Lenoir G, Bijlsma E, Fahsold R, Dumanski J, de Jong P, Parry D, Eldridge R, Aurias A, Delattre O, Thomas G. Alteration in a new gene encoding a putative membrane-organizing protein causes neurofibromatosis type 2. Nature 1993;363:515-521.

7. Trofatter JA, MacCollin MM, Rutter JL, Murrell JR, Duyao MP, Parry DM, Eldridge R, Kley N, Menon AG, Pulaski K, Haase VH, Ambrose CM, Munroe D, Bove C, Haines JL, Martuza RL, MacDonald ME, Seizinger BR, Short MP, Buckler AJ, Gusella JF. A novel moesin-, ezrin-, radixin-like gene is a candidate for the neurofibromatosis 2 tumor suppressor. Cell 1993;72:791-800.

8. Evans DGR, Huson SM, Donnai D, Neary W, Blair V, Teare D, Newton V, Strachan T, Ramesden R, Harris R. A genetic study of type 2 neurofibromatosis in the northwest of England and the UK: I. Prevalence, mutation rate, fitness and confirmation of maternal transmission effect on severity. J Med Genet 1992;29:841-846.

9. Evans DGR, Wallace A, Wu C, Trueman L, Ramsden R, Strachan T. Somatic mosaicism: a common cause of classic disease in tumor-prone syndromes? Lessons from type 2 neurofibromatosis. Am J Hum Genet 1998;63:727-736.

10. Kluwe L, Mautner VF. Mosaicism in sporadic neurofibromatosis 2 patients. Hum Mol Genet 1998;7:2051-2055.

11. Gutmann D, Aylsworth A, Carey J, Korf B, Marks J, Pyeritz R, Rubenstein A, Viskochil $\mathrm{D}$. The diagnostic evaluation and multidisciplinary management of neurofibromatosis 1 and neurofibromatosis 2. JAMA 1997;278:51-57.

12. Kluwe L, Mautner VF, Parry DM, Jacoby LB, Baser M, Gusella J, Davis K, Stavrou D, MacCollin M. Parental origin of de novo mutations in sporadic neurofibromatosis 2 patients. Neurogenetics 2000;3:17-24.

13. Dunham I, Shimizu N, Roe BA, Chissoe S, Hunt AR, Collins JE, Bruskiewich R, Beare DM, Clamp M, Smink LJ, Ainscough R, Almeida JP, Babbage A, Bagguley C, Bailey J, Barlow K, Bates KN, Beasley O, Bird CP, Blakey S, Bridgeman AM, Buck D, Burgess J, Burrill WD, O’Brien KP, et al. The DNA sequence of human chromosome 22. Nature 1999;402:489-495.

14. Merel P, Hoang-Xuan K, Sanson M, Bijlsma E, Rouleau G, Laurent-Puig P, Pulst S, Baser M, Lenoir G, Sterkers JM, Philippon J, Resche F, Mautner VF, Fischer G,
Hulsebos T, Aurias A, Delattre O, Thomas G. Screening for germ-line mutations in the NF2 gene. Genes Chromosomes Cancer 1995;12:117-127.

15. Kluwe L, Bayer S, Baser ME, Hazim W, Haase W, Funsterer C, Mautner VF. Identification of NF2 germ-line mutations and comparison with neurofibromatosis 2 phenotypes. Hum Genet 1996;98:534-538.

16. Parry DM, MacCollin M, Kaiser-Kupfer MI, Pulaski K, Nicholson HS, Bolesta M, Eldridge R, Gusella JF. Germ-line mutations in the neurofibromatosis 2 gene: correlations with disease severity and retinal abnormalities. Am J Hum Genet 1996;59: $529-539$.

17. Ruttledge MH, Andermann A, Phelan CM, Claudio JO, Han F, Chretien N, Rangaratnam S, MacCollin M, Short P, Parry D, Michels V, Riccardi V, Weksberg R, Kitamura K, Brandburn JM, Hall BD, Propping P, Rouleau GA. Type of mutation in the neurofibromatosis type 2 gene (NF2) frequently determines severity of disease. Am J Hum Genet 1996;59:331-342.

18. Evans DGR, Trueman L, Wallace A, Collins S, Strachan T. Genotype/phenotype correlations in type 2 neurofibromatosis (NF2): evidence for more severe disease associated with truncating mutations. J Med Genet 1998;35:450-455.

19. MacCollin M, Woodfin W, Kronn D, Short M. Schwannomatosis: a clinical and pathologic study. Neurology 1996;46:1072-1079.

20. Jacoby LB, Jones D, Davis K, Kronn D, Short MP, Gusella J, MacCollin M. Molecular analysis of the NF2 tumor-suppressor gene in schwannomatosis. Am J Hum Genet 1997;61:1293-1302.

21. Kluwe L, Friedrich RE, Hagel C, Lindenau M, Mautner V-F. Mutations and allelic loss of the NF2 gene in neurofibromatosis 2-associated skin tumors. J Invest Dermatol 2000;114:1017-1021.

22. Lohmann DR, Brandt B, Oehlschlager U, Gottmann E, Hopping W, Passarge E, Horsthemke B. Molecular analysis and predictive testing in retinoblastoma. Ophthalmic Genet 1995;16:135-142.

23. Kwiatokowska J, Wigowska-Sowinska J, Napierala D, Slomski R, Kwiatokowski DJ. Mosaicism in tuberous sclerosis as a potential cause of the failure of molecular diagnosis. N Engl J Med 1999;340:703-707.

24. Murgia A, Martella M, Vinanzi C, Polli R, Perilongo G, Opocher G. Somatic mosaicism in von Hippel-Lindau disease. Hum Mut 2000;15:115-119.

25. Huson SM. Recent developments in the diagnosis and management of neurofibromatosis. Arch Dis Child 1989;64:745-749. 